\title{
Neoplecostomus doceensis: a new loricariid species (Teleostei, Siluriformes) from the rio Doce basin and comments about its putative origin
}

\author{
Fábio F. Roxo', Gabriel S. C. Silva', Cláudio H. Zawadzki², Claudio Oliveira' \\ I Universidade Estadual Paulista, UNESP, Departamento de Morfologia, Laboratório de Biologia e Genética \\ de Peixes, 18618-000, Botucatu,São Paulo State, Brazil 2 Universidade Estadual de Maringá, Departamento \\ de Biologia, Núcleo de Pesquisas em Limnologia, Ictiologia e Aquicultura (Nupélia), 87020-900, Maringá, \\ Paraná State, Brazil \\ Corresponding author: Fábio F. Roxo (roxoff@hotmail.com.br)
}

Academic editor: N. Bogutskaya | Received 7 July 2014 | Accepted 4 September 2014 | Published 15 September 2014

http://zoobank.org/A9BEA380-98B8-4A13-8B96-92A5BA06C090

Citation: Roxo FF, Silva GSC, Zawadzki CH, Oliveira C (2014) Neoplecostomus doceensis: a new loricariid species (Teleostei, Siluriformes) from the rio Doce basin and comments about its putative origin. ZooKeys 440: 115-127. doi: $10.3897 /$ zookeys.440.8203

\begin{abstract}
A new species of Neoplecostomus is described from the rio Doce basin representing the first species of this genus in the basin. The new species is distinguished from its congeners by having enlarged, fleshy folds between dentaries, two or three series of developed papillae anterior to premaxillary teeth and a adiposefin membrane present, and by lacking enlarged odontodes along snout lateral margins in mature males, a well-developed dorsal-fin spinelet wider than dorsal-fin spine base, lower number of lateral-line plates and developed membrane on the dorsal portion of the first, second and third pelvic-fin branched rays. Additionally, we present a brief discussion of biogeographic scenarios that may explain the distribution of the new species in the rio Doce basin. We suggested that the ancestral lineage of the new species reached the rio Doce from the upper portions of rio Paraná drainages about 3.5 Mya (95\% HPD: 1.6-5.5) indicating a colonization route of the $N$. doceensis ancestral lineage from the south end of Serra do Espinhaço, probably as a result of headwater capture processes between the upper rio Paraná and rio Doce basins.
\end{abstract}

\section{Keywords}

Brazilian shield, catfishes, freshwater, ichthyology, Neoplecostominae, Neotropical fishes, Ostariophysi

Copyright Fábio F. Roxo et al. This is an open access article distributed under the terms of the Creative Commons Attribution License (CC BY 4.0), which permits unrestricted use, distribution, and reproduction in any medium, provided the original author and source are credited. 


\section{Introduction}

Neoplecostominae currently includes six genera: Neoplecostomus, Isbrueckerichthys, Kronichthys, Pareiorhaphis, Pareiorhina and Pseudotocinclus (Armbruster 2004; Chiachio et al. 2008; Roxo et al. 2012a, b) and more than 50 valid species (Eschmeyer and Fong 2014) distributed throughout the southeastern drainage regions in South America, from Rio Grande do Sul to Bahia states, except for Pareiorhaphis regani, which occurs in the rio Negro, in the Amazon basin.

Since Langeani (1990), the genus Neoplecostomus has been diagnosed as having a conspicuous series of enlarged papillae just posterior to the dentary teeth, which are larger than those on the remaining portions of the lower lip, the abdomen covered with platelets forming either a pentagonal or hexagonal shield, and the canal bearing plate on the cheek and the dorsal locking mechanism absent. Presently, the genus includes 13 species (Eschmeyer 2014): N. paranensis Langeani, 1990, N. corumba Zawadzki, Pavanelli \& Langeani, 2008, N. selenae Zawadzki, Pavanelli \& Langeani, 2008, N. yapo Zawadzki, Pavanelli \& Langeani, 2008, N. botucatu Roxo, Oliveira \& Zawadzki, 2012, N. bandeirante Roxo, Oliveira \& Zawadzki, 2012, N. langeanii Roxo, Oliveira \& Zawadzki, 2012, all from the upper rio Paraná basin; N. franciscoensis, Langeani, (1990) from the rio São Francisco basin; N. microps (Steindachner, 1877), N. variipictus Bizerril, 1995, and $N$. granosus (Cuvier \& Valenciennes, 1840) from the rio Paraíba do Sul basin; N. espiritosantensis Langeani, 1990 from rio Jacu basin and N. ribeirensis Langeani (1990) from rio Ribeira de Iguape basin.

An examination of the fish collections at the LBP (Laboratório de Biologia e Genética de Peixes de Botucatu - São Paulo); MCNIP (Museu de Ciências Naturais da PUC Minas - Minas Gerais); MZUSP (Museu de Zoologia de São Paulo - São Paulo); and NUP (Coleção Ictiológica do Núcleo de Pesquisas em Limnologia, Ictiologia e Aquicultura, Universidade Estadual de Maringá - Paraná) revealed the existence of an undescribed species of Neoplecostomus from the rio Doce, the first species of the genus described from this basin. Additionally, we present a brief discussion of biogeographic scenarios that may explain the distribution of the new species in the rio Doce basin.

\section{Material and methods}

Measurements and counts were taken on the left side of the specimens. Body plate nomenclature follows Schaefer (1997) and measurements follow Langeani (1990), modified by Zawadzki et al. (2008), and are shown in Table 1. All measurements were taken point to point with digital callipers to the nearest $0.1 \mathrm{~mm}$. Specimens were cleared and stained (c\&s) according to the method of Taylor and Van Dyke (1985). Dorsal-fin ray counts included the spinelet as the first unbranched ray. Vouchers were deposited in the collections of the (LBP) Laboratório de Biologia e Genética de Peixes, Universidade Estadual Paulista, Botucatu, Brazil; (MCNIP) Museu de Ciências Naturais da PUC Minas, Minas Gerais, Brazil; (MZUSP) Museu de Zoologia da Universidade de São 
Paulo, São Paulo, Brazil; (NUP) Coleção Ictiológica do Nupélia, Universidade Estadual de Maringá, Maringá, Brazil. The scientific names of the species follow the International Code of Zoological Nomenclature (International Commission on Zoological Nomenclature 1999).

\section{Results}

Neoplecostomus doceensis sp. $\mathbf{n}$. http://zoobank.org/28057609-4191-4808-B6C0-7DABFD0E73D2 Figure 1; Table 1

“Neoplecostomus sp. 9" - Roxo et al. 2012a: 2443 [phylogenetic relationships]. - Roxo et al. 2012b: 38 [phylogenetic relationships].

Holotype. MZUSP 115486 (1 male 101.1 mm SL), Brazil, Minas Gerais State, municipality of Ouro Preto, córrego Bananeiras, affluent of rio Gualaxo do Norte, rio Doce basin, $20^{\circ} 14^{\prime} 20^{\prime \prime}$ S, 432 $28^{\prime} 40^{\prime \prime W}$, Abril 2010, BP Maia.

Paratypes. All from Brazil, Minas Gerais State, rio Doce basin (97 specimens).

LBP 1098 (1 female 40.9, 1 male c\&s $57.3 \mathrm{~mm} \mathrm{SL}$ ), municipality of Alto Rio Doce, rio Xopotó, $21^{\circ} 08^{\prime} 56 " \mathrm{~S}, 43^{\circ} 23^{\prime} 58^{\prime \prime W}$, October 2001, JC Oliveira, Al Alves, LR Sato. LBP 12261 (3 females 28.7-46.2 mm SL), municipality of Desterro do Melo, rio Xopotó, $21^{\circ} 09^{\prime} 09^{\prime \prime S}, 43^{\circ} 31^{\prime} 37^{\prime \prime W}$, October 2011, A Ferreira, FF Roxo, GSC Silva. LBP 18981 ( 2 females 58.3-82.0 mm SL), uncertain location of the rio Piranga, 19 November 2000, JC Oliveira, OT Oyakawa. MCNIP 439 (3 males 80.6-86.7 mm SL), municipality of São José do Mantimento, rio José Pedro, affluent of rio Manhua-

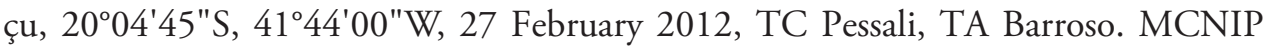
1169 (1 female 59.4 mm SL, 4 males 75.0-100.3 mm SL), municipality of São José do

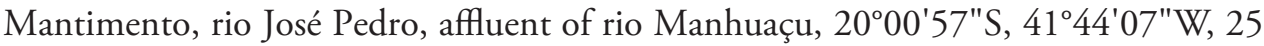
September 2013, TC Pessali, GM Santos. MZUSP 69368 (2 females 70.6-88.0 mm SL), municipality of Coroací, rio Suaçuí Pequeno (at bridge of Procópio), 1841'38"S, $42^{\circ} 12^{\prime} 50 " W, 29$ April 2001, AM Zanatta. MZUSP 80971 (3 males 70.8-96.3 mm SL), municipality of São Luiz, rio Manhuaçu, 20²0'11"S, 42042'48"W, 21 April 2002, CBM Alves. MZUSP 94487 (1 female $54.1 \mathrm{~mm} \mathrm{SL}$ ), municipality of Alto Rio Doce, rio Xopotó, rio Doce basin, $21^{\circ} 04^{\prime} 04^{\prime \prime S}, 43^{\circ} 27^{\prime} 50^{\prime W}, 11$ July 2007, OT Oyakawa. MUZSP 94505 (6 females 31.4-40.5 mm SL) municipality of Desterro do Melo, rio

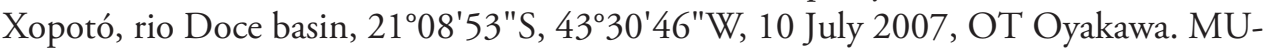
ZSP 94514 (1 female $35.8 \mathrm{~mm} \mathrm{SL}$ ) municipality of Alto Rio Doce, rio Xopotó, rio

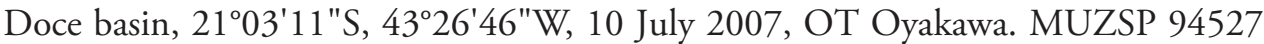
(7 females 33.7-41.5 mm SL) municipality of Desterro do Melo, rio Xopotó, rio

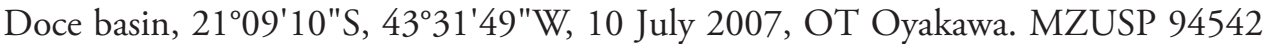
(1 male $53.1 \mathrm{~mm} \mathrm{SL}, 7$ females 37.7-53.9 mm SL) municipality of Desterro do Melo, rio Xopotó, rio Doce basin, $21^{\circ} 09^{\prime} 10^{\prime \prime S}, 43^{\circ} 31^{\prime} 28^{\prime \prime W}, 10$ July 2007, OT Oyakawa. 


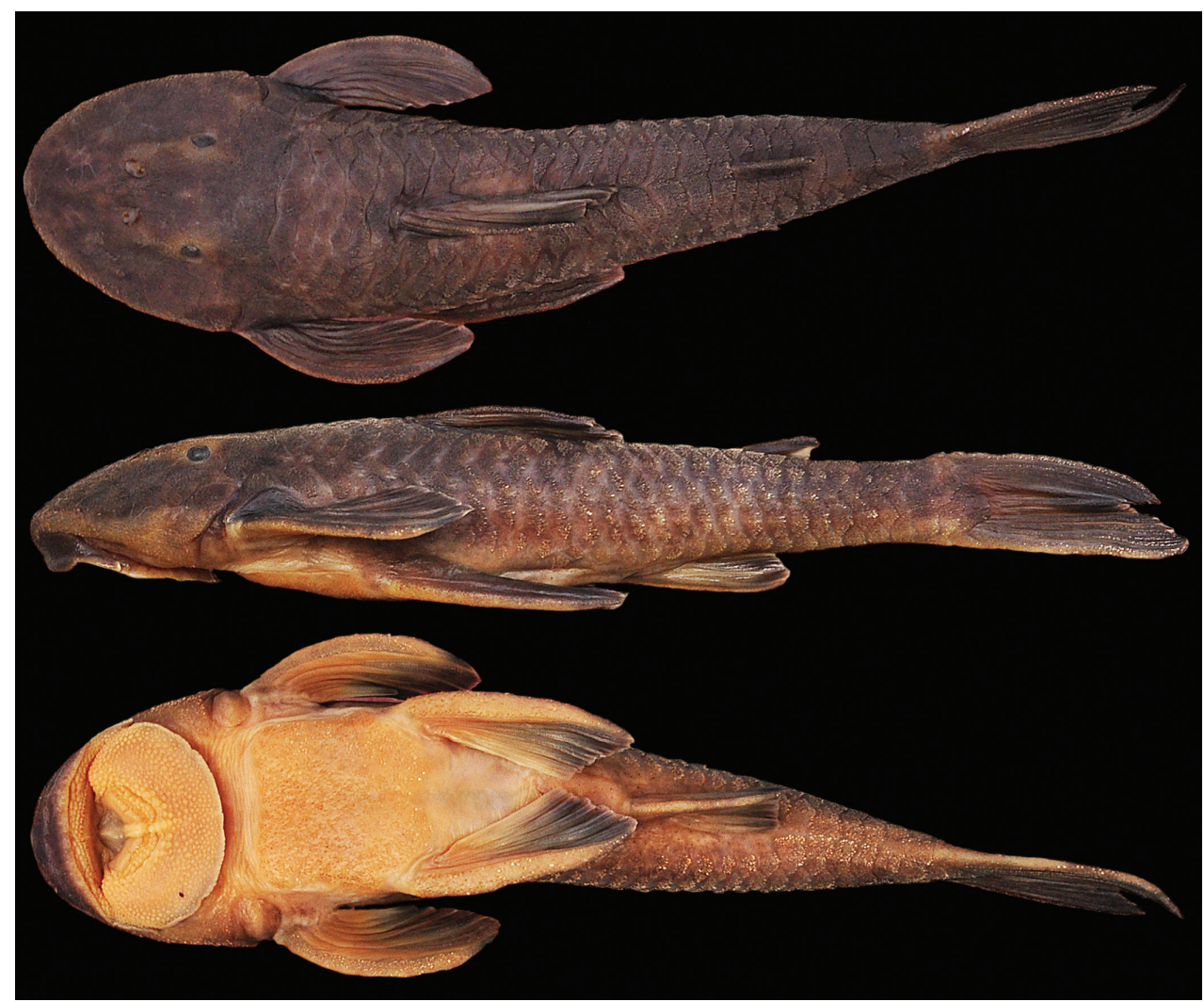

Figure I. Neoplecostomus doceensis, MZUSP 115486, male, $101.1 \mathrm{~mm} \mathrm{SL}$, holotype from the affluent of rio Gualaxo do Norte, rio Doce basin, municipality of Ouro Preto, Minas Gerais State, Brazil.

MZUSP 107368 (2 males 61.1-84.5 mm SL, 3 females 47.8-79.5 mm SL), uncertain location of the rio Piranga, 19 November 2000, JC Oliveira, OT Oyakawa. MZUSP 109327 (9 males 55.3-90.6 mm SL, 29 females 32.2-93.6 mm SL), municipality of Manhuaçu, affluent of the rio Manhuaçu, 20¹7'34"S, 4203'41"W, October 2008, TC Pessali. MZUSP 109339 (1 male 51.7 mm SL, 2 females 53.8-69.6 mm SL) collected with holotype. MUZUSP 110931 (2 males 63.7-80.7 mm SL), municipality of Mariana, rio Gualaxo do Sul, 20³0'17"S, 4324'40"W, July 2012, LF Salvador, LAC Missiaggia. NUP 17003, (1 female 83.2 mm SL, 2 males 96.6-100.3 mm SL), municipality of São José do Mantimento, rio José Pedro, affluent of rio Manhuaçu, $20^{\circ} 00^{\prime} 57^{\prime} \mathrm{S}, 4^{\circ} 44^{\prime} 07^{\prime \prime W}, 25$ September 2013, TC Pessali, GM Santos. NUP 17004, (3 males 89.4-97.7 mm SL), municipality of São José do Mantimento, rio José Pedro,

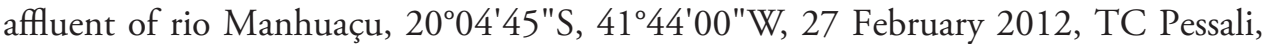
TA Barroso.

Non-type specimens. LBP 1096 (2 unsexed 54.4-57.7 mm SL), municipality of Alto Rio Doce, rio Xopotó, 21 $08^{\prime} 56^{\prime \prime S}, 43^{\circ} 23^{\prime} 58^{\prime \prime W}$, October 2001, JC Oliveira, AL Alves, LR Sato. 
Diagnosis. Neoplecostomus doceensis is distinguished from all other congeners by having enlarged, fleshy folds between dentaries in all specimens, more evident in mature males, Fig. 2a (vs. absence of the enlarged fleshy folds, Fig. 2b). The new species can also be distinguished from all congeners by the presence of two or three series of well-developed papillae anterior to premaxillary teeth, Fig. 2c (vs. papillae poorly developed or absent Fig. 2d). Additionally, the new species can be distinguished from $N$. botucatu and $N$. paranensis by the presence of a fully-developed adipose fin (vs. lacking or reduced adipose fin); from $N$. selenae by moderately-sized odontodes along lateral margins of snout and snout without swollen skin in mature males (vs. presence of large-sized odontodes surrounded by swollen skin along lateral margins of snout in mature males); from $N$. franciscoensis and $N$. ribeirensis by having a well-developed dorsal-fin spinelet, wider than dorsal-fin spine base (vs. absent or narrower than dorsalfin spine base); from $N$. microps and $N$. variipictus by a higher number of dentary teeth 12-35 (vs. 5-12 and 7 respectively); from $N$. granosus by having a lower number of lateral-line plates, 25-29 (vs. 34-43); from $N$. langeanii by the presence of a developed membrane on the dorsal portion of the first, second and third pelvic-fin branched rays (vs. lacking).

Description. Counts and measurements are presented in Table 1. Body robust, elongated and depressed, greatest width at cleithrum (25.8-28.7\% SL), narrowing to caudal peduncle. Dorsal profile of the head elevating and gently convex from snout tip to posterior margin of nares, straight to slightly concave to posterior margin of parieto supraoccipital, straight to dorsal-fin origin. Dorsal profile of trunk slightly concave and descending from dorsal-fin origin to adipose-fin origin, almost straight and descending to first procurrent caudal-fin ray; greatest body depth at dorsal-fin origin (15.3-19.6\% SL). Ventral profile slightly convex from snout tip to anal-fin origin; concave at analfin region, straight and ascending to lower caudal-fin ray. Trunk and caudal peduncle almost ellipsoid in cross-section, rounded laterally and almost flat dorsally and ventrally.

Dorsal body surface completely covered by dermal plates, except for a naked area around dorsal-fin base and a small naked area at snout tip. Ventral head surface naked except for a plate bearing odontodes in front of gill openings. Abdomen with conspicuous, small dermal platelets between insertions of pectoral and pelvic fins, forming a thoracic shield surrounded by naked areas. Abdominal platelets densely covered by backward-oriented odontodes, their tips round. Head wide (79.8-90.8\% HL) and depressed (47.1-57.1\% HL). Head and snout rounded in dorsal view; interorbital space straight to slightly concave in frontal view.

Snout tip with a weak ridge between nares, sometimes absent, more evident in larger specimens. A weak ridge from middle of snout to superior margin of orbit. Moderate-sized odontodes along lateral margins of snout, more evident in mature males. Eye moderately small $(7.0-11.2 \% \mathrm{HL})$ and dorso-laterally placed; lips well developed and rounded; lower lip almost reaching pectoral girdle and covered with papillae, wider anteriorly. Enlarged fleshy folds among dentary, more evident in mature males (Fig. 2a). Two to three irregular and conspicuous rows of large and transversally flattened papillae along and posterior to dentary teeth and anterior to premaxillary 
Table I. Morphometric and meristics of Neoplecostomus doceensis (holotype and paratypes). SD = standard deviation.

\begin{tabular}{|c|c|c|c|c|c|}
\hline & \multicolumn{5}{|c|}{ Neoplecostomus doceensis $\mathrm{n}=26$} \\
\hline & Holotype & Min & Max & Mean & SD \\
\hline SL & 101.1 & 40.9 & 101.1 & 72.4 & 16.3 \\
\hline \multicolumn{6}{|l|}{ Percents of SL } \\
\hline Predorsal length & 43.2 & 42.5 & 47.0 & 43.8 & 0.9 \\
\hline Head length & 31.1 & 31.0 & 33.1 & 32.3 & 0.6 \\
\hline Head width & 28.2 & 25.7 & 28.5 & 27.5 & 0.7 \\
\hline Cleithral width & 26.3 & 25.8 & 28.7 & 27.1 & 0.8 \\
\hline Occipital-dorsal distance & 12.1 & 10.7 & 13.8 & 12.3 & 0.7 \\
\hline Thoracic length & 17.9 & 14.6 & 18.6 & 17.2 & 1.1 \\
\hline Interdorsal length & 19.9 & 16.9 & 22.0 & 18.9 & 1.3 \\
\hline Caudal peduncle length & 28.3 & 27.3 & 38.7 & 31.3 & 3.2 \\
\hline Caudal peduncle depth & 8.7 & 6.5 & 8.7 & 7.4 & 0.5 \\
\hline Body depth & 19.6 & 15.3 & 19.6 & 17.5 & 1.2 \\
\hline Preanal length & 65.1 & 59.0 & 67.0 & 64.3 & 1.9 \\
\hline \multicolumn{6}{|l|}{ Percents of HL } \\
\hline Head width & 90.7 & 79.8 & 90.8 & 85.2 & 2.6 \\
\hline Head depth & 56.5 & 47.1 & 57.1 & 51.9 & 2.7 \\
\hline Snout length & 69.1 & 62.7 & 69.2 & 65.9 & 1.9 \\
\hline Orbital diameter & 7.9 & 7.0 & 11.2 & 8.8 & 1.2 \\
\hline Interorbital width & 32.5 & 29.3 & 34.1 & 31.6 & 1.3 \\
\hline Mandibullary width & 18.8 & 12.5 & 22.4 & 18.2 & 2.6 \\
\hline \multicolumn{6}{|l|}{ Other percents } \\
\hline Snout length/Orbital diameter & 11.4 & 10.6 & 17.7 & 13.3 & 1.9 \\
\hline Interorbital/Orbital diameter & 24.3 & 23.3 & 33.7 & 27.8 & 3.4 \\
\hline Interorbital/mandibullary width & 57.9 & 44.3 & 74.4 & 58.6 & 8.4 \\
\hline Predorsal length/first ds ray length & 46.0 & 41.8 & 51.1 & 46.1 & 1.8 \\
\hline Caudal peduncle length/Caudal peduncle depth & 30.6 & 18.5 & 30.7 & 23.7 & 3.0 \\
\hline Pelvic-fin length/Caudal peduncle depth & 33.9 & 25.4 & 36.5 & 29.5 & 2.6 \\
\hline Lower cd spine/Caudal peduncle depth & 31.6 & 22.3 & 35.4 & 26.7 & 2.8 \\
\hline Meristics & Holotype & Min & Max & Mode & SD \\
\hline Lateral-line plates & 27 & 25 & 29 & 27 & 1 \\
\hline Predorsal plates & 6 & 4 & 7 & 6 & 1 \\
\hline Plates of dorsal-fin base & 6 & 5 & 6 & 6 & 0 \\
\hline Plates between dorsal and caudal & 15 & 15 & 18 & 16 & 1 \\
\hline Plates between adipose and caudal & 5 & 5 & 6 & 5 & 0 \\
\hline Plates between an and caudal & 11 & 10 & 13 & 12 & 1 \\
\hline Premaxillary teeth & 26 & 14 & 33 & 22 & 6 \\
\hline Dentary teeth & 20 & 12 & 35 & 20 & 6 \\
\hline
\end{tabular}

teeth (Fig. 2c). Maxillary barbel very short, coalesced, usually its tip not free from lower lip. Teeth long, slender and bicuspid; mesial cusp longer than lateral; dentary ramus forming an angle of approximately $125-130^{\circ}$. 


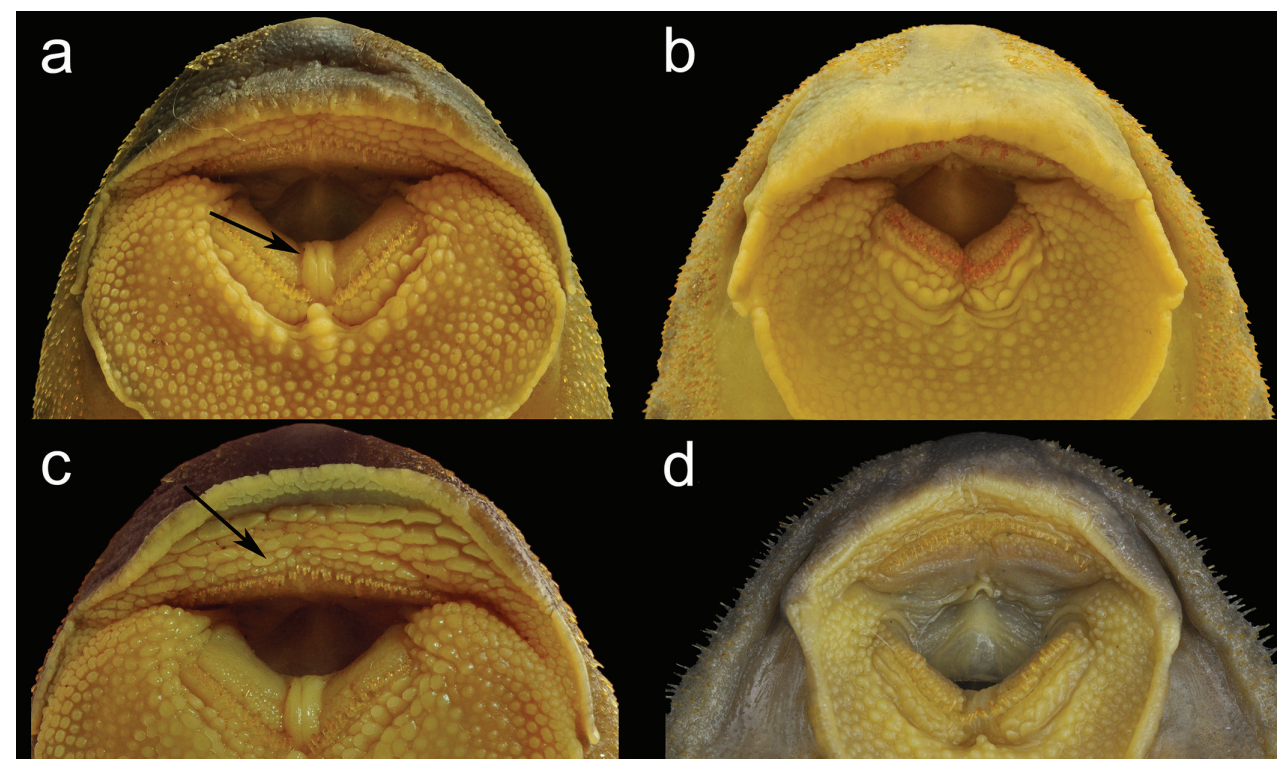

Figure 2. a Neoplecostomus doceensis, MZUSP 115486, $101.1 \mathrm{~mm}$ SL, male, holotype, arrow showing the developed papillae between dentaries b $N$. botucatu, MZUSP 110364, $98.6 \mathrm{~mm}$ SL, male, paratype, lacking the papillae between dentaries $\mathbf{c} N$. doceensis, MZUSP 115486, $101.1 \mathrm{~mm}$ SL (male), holotype, arrow showing the developed papillae series anterior to premaxillary teeth $\mathbf{d} N$. selenae, MZUSP 51889, $101.7 \mathrm{~mm}$ SL, male, paratype, lacking the papillae series anterior to premaxillary teeth.

Dorsal fin II,7; origin slightly posterior to pelvic-fin origin; dorsal-fin spinelet semicircular and wider than dorsal-fin spine base (spinelet hardly visible in some specimens, but always present); dorsal-fin locking mechanism not functional; dorsal-fin posterior margin straight to slightly rounded, reaching end of pelvic-fin rays when adpressed. Adipose-fin well developed and always present, preceded by azygous plate. Pectoral-fin I,6; unbranched ray depressed and curved inward (more pronounced in larger specimens), shorter than longest branched ray; posterior margin slightly concave, almost reaching half pelvic-fin ray length when adpressed; unbranched ray anteroventrally covered with backward-oriented odontodes. Pelvic-fin I,5; posterior margin nearly straight, reaching anal-fin insertion when adpressed; pelvic-fin unbranched ray ventrally flattened, with dermal flap on its dorsal surface in males; first and second branched rays also with dermal flap on its dorsal surface in males; unbranched ray anteroventrally covered with backward-oriented odontodes. Anal-fin I,5; posterior margin nearly straight; unbranched ray ventrally covered with back-oriented odontodes. Caudal-fin I,7,7,I; bifurcated; lower spine longer than upper; pectoral spine and unbranched pelvic-fin rays with odontodes on lateral and ventral portions.

Color in alcohol. Ground color of dorsal surface of head and body dark brown to lighter brown in some specimens. Head with a pale spot on naked area of snout tip; orbital margin slightly lighter, mainly on its superior portion; small pale spot on interorbital space; lateral margin of snout usually lighter than rest of dorsal surface of 


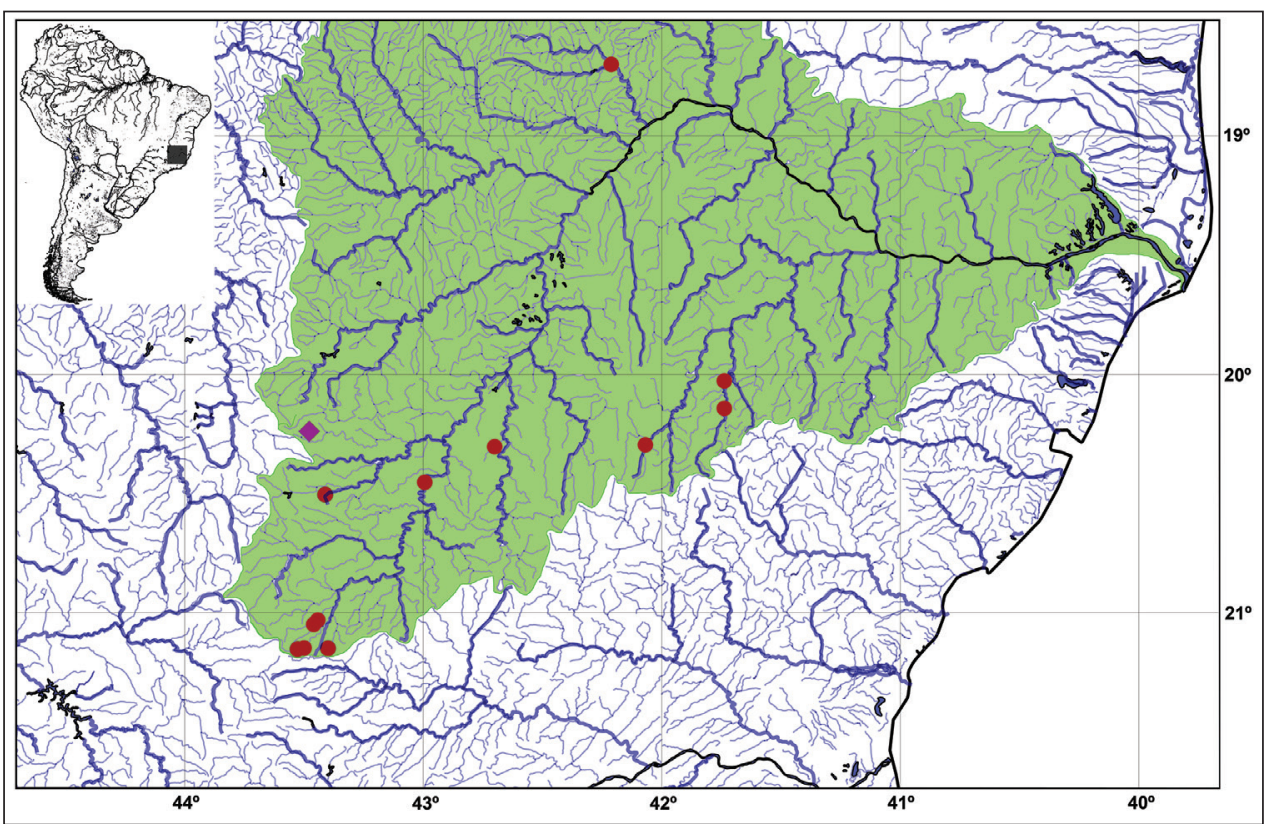

Figure 3. Map showing the type locality (pink diamond), $20^{\circ} 14^{\prime} 20^{\prime \prime S}, 43^{\circ} 28^{\prime} 40^{\prime \prime} \mathrm{W}$, and paratypes (red circles) of Neoplecostomus doceensis at the rio Doce basin (green highlighted drainages). See Distribution and Paratypes sections for details about each paratype localities.

head. Body dorsal color pattern in most specimens with four transverse light bands: first through supraoccipital, second in middle of dorsal-fin, third posterior to dorsalfin, fourth posterior to adipose-fin. Body lateral portion with an upper darker and a lower lighter, just below lateral line. Dorsal, pectoral, pelvic, anal and caudal fins with hard visible irregular series of dark spots on rays. Ventral surface of head and body light brown.

Sexual dimorphism. Males with papilla at the urogenital opening and a membrane along the dorsal portion of the unbranched pelvic-fin ray. Males seem to reach a greater length.

Distribution. Neoplecostomus doceensis is known from thirteen localities: one at rio Gualaxo do Norte, one at rio Gualaxo do Sul, one at rio José Pedro, one at rio Piranga, three at rio Manhuaçu, one at rio Suaçuí Pequeno and five at rio Xopotó, all in the rio Doce Basin, Minas Gerais State, Brazil (Fig. 3).

Ecological notes. Neoplecostomus doceensis is found in clear water rivers, varying from small to medium sized, with rocky outcrops forming small waterfalls and substrates of rocks and sand. The species is found at the bottom of the rivers among the rocks.

Etymology. The specific name doceensis is a Latin noun meaning being located or having connection with the rio Doce basin. This hydrographic system is located in the southeastern region of Brazil and comprises a drainage area of $83,400 \mathrm{~km}^{2}$, on the border of Minas Gerais and Espirito Santo states. 


\section{Discussion}

\section{Taxonomy}

Neoplecostomus doceensis has a conspicuous series of enlarged papillae just posterior to the dentary teeth, which are larger than those on the remaining portions of the lower lip. The abdomen is covered with platelet shields of pentagonal, hexagonal or heptagonal shape. The canal bearing plate and the dorsal locking mechanism are absent, suggesting that this is a typical species of the genus Neoplecostomus, sensu Langeani (1990).

The main character used to distinguish the new species from its congeners is the enlarged fleshy folds between dentaries present in all specimens (Fig. 2a). Apparently, these folds can also be present in some large specimens of $N$. selenae, although it is poorly developed. Within $N$. doceensis, this character was observed in specimens of all sizes. However, it is more developed in mature males. Within $N$. yapo, we found variations of the folds between dentaries. In specimens of $N$. yapo of the rio Verde, municipality of Ponta Grossa (NUP 4300), this character is poorly developed, as in $N$. selenae and in specimens of the rio Atlântico, municipality of Mandaguaçu (NUP 4851), in which this character is absent. Several authors (e.g. Langeani 1990; Bizerril 1995; Zawadzki et al. 2008; Roxo et al. 2012c) have reported that the characters used to define the species of Neoplecostomus are influenced by both the sex and stage of ontogenetic development, which also occurs with the papillae between the dentary teeth.

The presence of two or three series of well-developed papillae anterior to the premaxillary teeth also distinguish the new species from its congeners (Fig. 2c). The presence of two or three series of conspicuous papillae just posterior to dentary teeth was previously discussed by Langeani (1990) and is used to diagnose the genus Neoplecostomus. Nevertheless, the papillae series anterior to premaxillary teeth have not previously been reported. Several species of Neoplecostomus such as $N$. bandeirante, $N$. corumba and $N$. ribeirensis have this character; however, it is best developed in $N$. doceensis. Apparently, this character is also influenced by sex and is enlarged in mature males.

\section{Biogeography and dispersal route}

Roxo et al. (2012a, 2012b), in a phylogenetic study of the Neoplecostominae species, suggested that Neoplecostomus originated within "interior running drainages" (i.e., drainages of the upper rio Paraná, rio Iguaçu, and rio São Francisco). An exception was found for $N$. ribeirensis, which appeared as a sister group to Isbrueckerichthys and originated in littoral drainages (i.e., Northeastern Mata Atlântica rivers, rio Paraíba do Sul, rio Ribeira de Iguape, Southeastern Mata Atlântica river, and Fluminense river). The new species, $N$. doceensis (cited as Neoplecostomus sp. 9 in Roxo et al. 2012a), is closely related to two undescribed species of Neoplecostomus, Neoplecostomus sp. 6 (from córrego do Sapateiro) and Neoplecostomus sp. 7 (from córrego Tamborete) both from streams in the rio Grande basin, an Atlantic coastal drainage. Roxo et al. (2012a) suggested that 


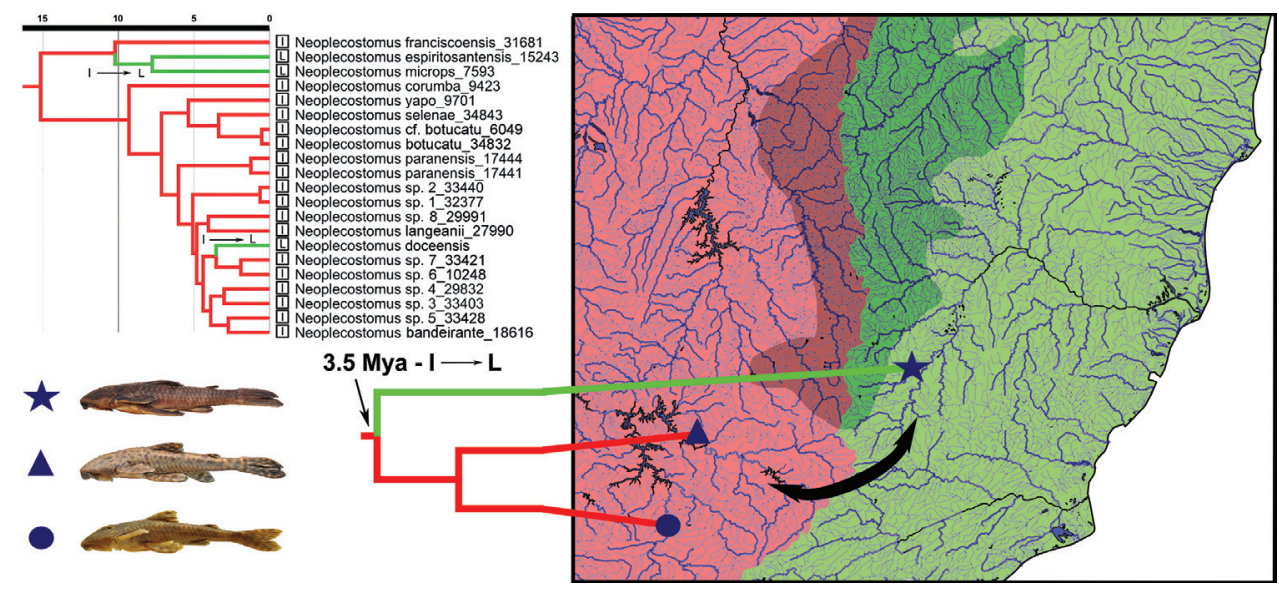

Figure 4. Distribution and time-calibrated phylogenetic tree of Neoplecostomus species, except N. ribeirensis, based on four mitochondrial (12S rRNA, 16SrRNA, COI, Cytb) and one nuclear marker (Freticulon 4), modified from Figure 3 of Roxo et al. (2012a). The red coloration in the figure indicates the interior drainages (Upper Paraná, Iguassu, and São Francisco) and the green, the littoral drainages (Northeastern Mata Atlântica, Paraíba do Sul, Ribeira de Iguape, Southeastern Mata Atlântica and Fluminense). Based on our hypothesis, the ancestral lineage of $N$. doceensis dispersed from the upper rio Paraná to rio Doce drainages about 3.5 Mya (95\% HPD: 1.6-5.5). See Table S1 in Roxo et al. (2012a) for all localities of undescribed species of Neoplecostomus.

the ancestor of $N$. doceensis (cited as Neoplecostomus sp. 9) reached the rio Doce basin about 3.5 million years ago (95\% HPD: 1.6-5.5) indicating a colonization route of the $N$. doceensis ancestral lineage from southern Serra do Espinhaço (Fig. 4), probably as a result of headwater capture processes between the upper rio Paraná and rio Doce basins.

Ribeiro (2006) suggested that the south-eastern region of Brazil has undergone intensive geological activity and that the activations of ancient faults could have resulted in headwater captures between adjacent drainages during several periods of its geological history. The eastern Brazilian coastal drainages have probably resulted in the capture of several adjacent rivers, including the headwaters of the Tietê, Grande, São Francisco and Doce rivers. A river capture event at this approximate time and place is also consistent with the General Area Cladogram of fish taxa from tropical South America (Albert and Carvalho 2011). This process is likely to have influenced the movement of ancestral fish throughout the adjacent drainages, similar to the geodispersal of the ancestor of $N$. doceensis from the upper rio Paraná drainages to the rio Doce drainages about $3.5 \mathrm{Mya}$ (95\% HPD: 1.6-5.5).

\section{Comparative material}

Neoplecostomus bandeirante: holotype, MZUSP 110363, 109.9 mm SL, rio Paraitinguinha, rio Tietê basin, paratypes, LBP 3921, 2, 88.0-94.9 mm SL, rio Paraitinguinha, 
rio Tietê basin, LBP 2861, 8, 87.6-106.4 mm SL, rio Paraitinguinha, rio Tietê basin, NUP 6103, 1, 101.7 mm SL, rio Paraitinguinha, rio Tietê basin; Neoplecostomus botucatu: holotype, MZUSP 110364, 98.6 mm SL, córrego Águas de Madalena, rio Paranapanema basin, paratype, LBP 7525, 10, 80.3-102.2 mm SL, córrego Águas de Madalena, rio Paranapanema basin, LBP 8065, 12, 67.5-88.2 mm SL, córrego Âguas de Madalena, rio Paranapanema basin, NUP 8016, 1, 69.8 mm SL, córrego Águas de Madalena, rio Paranapanema basin; Neoplecostomus corumba: holotype, DZSJRP 6713, $78.3 \mathrm{~mm}$ SL, córrego Gameleira, rio Paranaíba basin, paratypes, MZUSP 86208, 9, 45.7-77.6 mm SL, córrego Gameleira, rio Paranaíba basin; Neoplecostomus espiritosantensis: holotype, MZUSP 38573, 102.3 mm SL, rio Jucu, Coastal Drainage, LBP 2551, 2, 81.9-85.4 mm SL, rio Jucu, Coastal Drainage; Neoplecostomus franciscoensis: holotype, MZUSP 38577, 68.4 mm SL, affluent córrego Mutuca, rio São Francisco basin, LBP 6489, 50, 42.8-55.9 mm SL, rio das Velhas, rio São Francisco basin, MZUSP 107361, 7, 54.3-107.8 mm SL, rio Paraopeba, rio São Francisco basin; Neoplecostomus langeanii: holotype, MZUSP 110365, 85.5 mm SL, rio São Domingos, rio Grande basin, paratype, LBP 5931, 11, 48.4-69.6 mm SL, rio São Domingos, rio Grande basin, LBP 5947, 8, 56.6-73.5 mm SL, rio São Domingos, rio Grande basin; Neoplecostomus microps: LBP 6350, 4, 51.0-58.9 mm SL, rio Ribeirão Grande, rio Paraíba do Sul basin, LBP 8045, 31, 43.8-71.4 mm SL, ribeirão Piquete, rio Paraíba do Sul basin, LBP 8370, 17, 39.5-81.2 mm SL, rio Pomba, rio Paraíba do Sul basin; Neoplecostomus paranensis: holotype, MZUSP 38572, $71.4 \mathrm{~mm}$ SL, rio Cubatâo, rio Grande basin, LBP 2732, 1, 70.5 mm SL, córrego Mocoquinha, rio Grande basin, MZUSP 10213, 2, 39.4-41.5 mm SL, rio Carandaí, rio Grande basin, MZUSP 35397, 1, 38.4 mm SL, rio São João, rio Grande basin, MZUSP 36583, 2, 52.0-62.4 mm SL, rio Cubatão, rio Grande basin, MZUSP 36625, 1, 56 mm SL, rio São Bartolomeu, rio Grande basin, MZUSP 38822, 1, $92.8 \mathrm{~mm}$ SL, rio Cubatão, rio Grande basin, MZUSP 38823, 1, 87.7 mm SL, rio Cubatão, rio Grande basin, MZUSP, 38824, 1, $68.1 \mathrm{~mm}$ SL, rio Cubatáo, rio Grande basin; Neoplecostomus ribeirensis: LBP 7384, 16, 37.7-79.2 mm SL, rio Água Doce, rio Ribeira de Iguape basin; Neoplecostomus selenae: holotype, MZUSP 51889, $101.7 \mathrm{~mm}$ SL, ribeirão das Batéias, rio Paranapanema basin, paratype, DZSJRP 7449, 4, 56.5-95.8 mm SL, ribeirão das Batéias, rio Paranapanema basin, MZUSP 52589, 4, 42.8-64.9 mm SL, ribeirão das Batéias, rio Paranapanema basin, NUP 3572, 5, 48.0-84.8 mm SL, ribeirão das Batéias, rio Paranapanema basin; Neoplecostomus yapo: holotype, DZSJRP 6714, $97.4 \mathrm{~mm}$ SL, riacho Fortaleza, rio Paranapanema basin, paratype, MZUSP 86211, 7, 63.8-105.2 mm SL, affluent of rio Yapó, rio Paranapanema basin, NUP 2609, 15, 48.4-109.6 mm SL, riacho Fortaleza, rio Paranapanema basin, NUP 4300, 5, 73.5-89.1 mm SL, rio Verde, rio Paranapanema basin, NUP 4851, 11, 39.2-73.8 mm SL, rio Atlântico, rio Paranapanema basin.

\section{Acknowledgments}

The authors would like to thank Bruno Maia, Gilberto Savador and Tiago Pessali for sending fish specimens from the rio Doce basin to several ichthyological collections; 
Aléssio Datovo and Osvaldo Oyakawa for hosting museum visits; Celso Ikedo for taking pictures of the fish papillae; Maria Thereza for English review; James S. Albert and Victor A. Tagliacollo for reading the manuscript and giving valuable suggestions. This research was supported by the Brazilian agencies FAPESP (Fundação de Amparo à Pesquisa do Estado de Sáo Paulo, proc. 2012/01622-2 to GSCS) and by the MCT/CNPq (Conselho Nacional de Desenvolvimento Científico e Tecnológico) (Edital Universal, proc. N. 484716-2006-9 and grants from CHZ - proc. N. 310733/2013-8).

\section{References}

Albert JS, Carvalho TP (2011) Neogene assembly of modern faunas. In: Albert JS, Reis RE (Eds) Historical biogeography of Neotropical freshwater fishes. University of California Press, Berkeley, 119-136. doi: 10.1525/california/9780520268685.003.0007

Armbruster JW (2004) Phylogenetic relationships of the sucker-mouth armored catfishes (Loricariidae) with particular emphasis on the Hypostominae and the Ancistrinae. Zoological Journal of the Linnean Society 141: 1-80. doi: 10.1111/j.1096-3642.2004.00109.x

Bizerril CRSF (1995) Descrição de uma nova espécie de Neoplecostomus (Loricariidae, Neoplecostominae), com uma sinopse da composição taxonômica dos Loricariidae no leste brasileiro. Brazilian Archives of Biology and Technology 38: 693-704.

Chiachio MC, Oliveira C, Montoya-Burgos JI (2008) Molecular systematic and historical biogeography of the armored Neotropical catfishes Hypoptopomatinae and Neoplecostominae (Siluriformes: Loricariidae). Molecular Phylogenetics and Evolution 49: 606-617. doi: 10.1016/j.ympev.2008.08.013

Cuvier G, Valenciennes A (1840) Histoire naturelle des poissons. Tome quinzième. Suite du livre dix-septième. Siluroïdes. 15: 1-540, Pls. 421-455.

Eschmeyer W (2014) Catalog of fishes. Electronic publication in "World Wide Web". http:// www.calacademy.org/research/ichthyology/catalog [accessed 23 June 2014]

Eschmeyer WN, Fong JD (2014) Species by Family/Subfamily. http://research.calacademy.org/ research/ichthyology/catalog/SpeciesByFamily.asp [accessed 23 June 2014]

International Commission on Zoological Nomenclature (1999) International Code of Zoological Nomenclature, (4th Ed.) International Trust for Zoological Nomenclature.

Langeani F (1990) Revisão do gênero Neoplecostomus, com a descrição de quatro espécies novas do sudeste brasileiro (Ostariophysi, Siluriformes, Loricariidae). Comunicações do Museu de Ciências e Tecnologia da PUCRS, Série Zoologia 3: 3-31.

Ribeiro AC (2006) Tectonic history and the biogeography of the freshwater fishes from the coastal drainages of eastern Brazil: an example of faunal evolution associated with a divergent continental margin. Neotropical Ichthyology 4: 225-246. doi: 10.1590/S167962252006000200009

Roxo FF, Zawadzki CH, Alexandrou MA, Costa Silva GJ, Chiachio MC, Foresti F, Oliveira C (2012a) Evolutionary and biogeographic history of the subfamily Neoplecostominae (Siluriformes: Loricariidae). Ecology and Evolution 2: 2438-2449. doi: 10.1002/ece3.368 
Roxo FF, Zawadzki CH, Costa Silva GJ, Chiachio MC, Foresti F, Oliveira C (2012b) Molecular systematics of the armored neotropical catfish subfamily Neoplecostominae (Siluriformes, Loricariidae). Zootaxa 3390: 33-42.

Roxo FF, Oliveira C, Zawadzki CH (2012c) Three new species of Neoplecostomus (Teleostei: Siluriformes: Loricariidae) from the Upper Rio Paraná basin of southeastern Brazil. Zootaxa 3233: 1-12.

Schaefer SA (1997) The Neotropical cascudinhos: systematics and biogeography of the Otocinclus catfishes (Siluriformes: Loricariidae). Proceedings of the Academy of Natural Sciences of Philadelphia 148: 1-120.

Steindachner F (1877) Die Süsswasserfische des südöstlichen Brasilien (III). Sitzungsberichte der Kaiserlichen Akademie der Wissenschaften. Mathematisch-Naturwissenschaftliche Classe 74 (1): 559-694, Pls. 1-13.

Taylor WR, Van Dyke GC (1985) Revised procedures for staining and clearing small fishes and other vertebrates for bone and cartilage study. Cybium 9: 107-109.

Zawadzki CH, Pavanelli CS, Langeani F (2008) Neoplecostomus (Teleostei: Loricariidae) from the Upper Rio Paraná basin, Brazil, with description of three new species. Zootaxa 1757: 31-48. 